\title{
Level of skeletal muscle glucose transporter protein correlates with insulin-stimulated whole body glucose disposal in man
}

\author{
L. I. Koranyi ${ }^{1}$, R. E. Bourey ${ }^{1}$, H. Vuorinen-Markkola ${ }^{3}$, V.A. Koivisto ${ }^{3}$, M. Mueckler ${ }^{2}$, M.A.Permutt ${ }^{1}$ \\ and H. Yki-Järvinen ${ }^{3}$ \\ ${ }^{1}$ Metabolism Division, Department of Internal Medicine, ${ }^{2}$ Department of Cell Biology, Washington University School of Medicine, \\ St. Louis, Missouri, USA, and ${ }^{3}$ Second Department of Medicine, Helsinki University, Helsinki, Finland
}

Summary. The content of GLUT4 glucose transportermRNA and protein were measured in samples of the vastus lateralis muscle of normal volunteers subjected to a 4-h hyperinsulinaemic, euglycaemic clamp. Plasma glucose concentration was clamped at $5.3 \pm 0.1 \mathrm{mmol} / 1$, and serum insulin concentration was maintained at $740 \pm 5 \mathrm{pmol} / \mathrm{l}$. Whole body glucose uptake averaged $38.3 \pm 2.2 \mu \mathrm{mol} \cdot \mathrm{kg}^{-1} \cdot \mathrm{min}^{-1}, 62 \%$ of this being due to disposal via non-oxidative pathways. A significant correlation existed between basal levels of GLUT4 protein and the rate of whole body glucose disposal $(r=0.77, p<0.02)$ and non-oxidative glucose disposal $(r=0.80, p<0.02)$. There was no correlation between GLUT4 protein content and oxidative glucose disposal $(r=0.08$, NS). These observations are consistent with an important role for skeletal muscle GLUT4 protein in whole body glucose disposal.

Key words: Glucose transport, insulin, muscle, euglycaemic clamp, GLUT4.
Skeletal muscle is the major depot for insulin-stimulated glucose disposal in man [1]. The rate-limiting step for glucose disposal in muscle under certain conditions appears to be transport across the sarcolemma (cf. 2). Glucose transport in muscle is a facilitated diffusion process mediated by one or more membrane glycoproteins. Five tissue-specific facilitative glucose transporter isoforms have been identified in mammalian organisms [3]. GLUT4 is the major isoform expressed in insulin-sensitive tissues, and the relative level of expression among various rat tissues correlates well with the magnitude of insulin-stimulated glucose transport observed in those tissues $[4,5]$. The GLUT1 transporter may also be expressed in muscle, but if so, it is likely to be present at much lower levels [4]. Thus, the GLUT4 transporter is believed to be responsible for the bulk of insulin-stimulated glucose transport in fat and muscle tissue. No studies, however, have been reported concerning the relative importance of GLUT4 transporter with respect to whole body glucose disposal. To address this issue, we examined the level of GLUT4 protein and mRNA in samples of vastus lateralis muscle from young, normal subjects in whom insulin-stimulated glucose disposal was measured by means of a hyperinsulinaemic, euglycaemic clamp. We show a correlation between whole body glucose disposal under these conditions, and the level of GLUT4 transporter present in muscle. Furthermore, only the nonoxidative component of glucose disposal correlated with levels of GLUT4 protein.

\section{Subjects, materials and methods}

\section{Subjects}

Eleven young males (age $25 \pm 2$ years, body mass index [BMI] $23 \pm 1 \mathrm{~kg} / \mathrm{m}^{2}$ ) participated in the study. The subjects were healthy as determined by medical history, physical examination, routine laboratory tests, and determination of glycated haemoglobin. The subjects consumed a weight-maintaining diet containing at least $200 \mathrm{~g}$ of carbohydrate per day for 3 days prior to the study which was performed on the metabolic ward of the Second Department of Medicine, Helsinki University.

All subjects gave their informed consent prior to participation. The study protocol was approved by the Ethical Committee of the Helsinki University Central Hospital.

\section{Whole-body glucose uptake and indirect calorimetry measurements}

After an overnight fast, a euglycaemic clamp procedure was performed as previously described [1]. Insulin was administered as a primed-continuous infusion at $1.5 \mathrm{mU} \cdot \mathrm{kg}^{-1} \cdot \mathrm{min}^{-1}$. Plasma for determination of glucose and insulin concentrations was withdrawn from an intravenous catheter which had been placed retrogradely in an ipsilateral hand vein. Glucose was maintained at its fasting concentration by a variable infusion of $20 \%$ glucose. The glucose disposal rate was calculated from the glucose infusion rate [1]. The proportion of total glucose uptake that was oxidized during euglycaemic hyperinsulinaemia was determined with indirect calorimetry using a computerized flow-through canopy gas analyser system (Deltatrac Metabolic Monitor, Datex, Helsinki, Finland) at evenly spaced in- 
tervals during the $240-\mathrm{min}$ period $(40-80,120-160,200-240 \mathrm{~min})$ as previously described [6].

\section{Muscle biopsy}

Samples of the vastus lateralis muscle $(25-50 \mathrm{mg})$ were obtained under local anaesthesia using a Bergström needle prior to insulin infusion and rapidly plunged $(<5 s$ ) into liquid nitrogen. Samples were kept in liquid nitrogen or on dry ice until analysis.

\section{cRNA probe}

Human GLUT4 cDNA was isolated from a jejunal cDNA library [7] using rat GLUT4 as the probe [4]. Sequence analysis indicated that the 1.7 kilobase human dDNA insert was identical to the $\mathrm{hJHT}-3$ clone previously described by Fukumoto et al. [8]. This clone contains a 260 basepair intron at its 3 end. The cDNA was subcioned into a Bluescript SK + plasmid (Stratagene, La Jolla, Calif., USA). Transcription of ${ }^{32} \mathrm{P}$-labelled cRNA and synthetic $\mathrm{mRNA}$ with T3 or T7 RNA polymerase was performed according to protocols provided by the supplier.

\section{Quantitation of $m R N A$ and $D N A$}

Total tissue RNA was extracted using a modified guanidine thiocyanate, water saturated phenol/chloroform extraction method [5]. Samples were homogenized in $4 \mathrm{~mol} / \mathrm{l} \mathrm{GuSCN}$ containing octylphenol-ethylenoxide detergent (Nonident P-40, Sigma Co., St. Louis, Mo., USA). The quantity and quality of RNA were determined by absorbance at 260 and $280 \mathrm{~nm}$. The $\mathrm{A}_{2602280}$ ratios were $>2$ for all samples. Northern blot analysis of a pooled sample of RNA produced a single band (not shown). Quantitation of GLUT4 mRNA was performed using dot blot analysis of aliquots of total RNA $(0.5-10 \mu \mathrm{g})$ as previously described [5]. Dilutions of synthetic mRNA (0.5$1000 \mathrm{pg}$ ) and cDNA (1-1000 pg) were used as standards. Blots were hybridized for $16-18 \mathrm{~h}$ at $60^{\circ} \mathrm{C}$ in $50 \%$ formamide, $5 \times \mathrm{SSPE}$ ( $\mathrm{SSPE}=0.9 \mathrm{~mol} / \mathrm{l}$ sodium chloride, $5 \mathrm{mmol} / \mathrm{l} \mathrm{EDTA}$, and $50 \mathrm{mmol} / \mathrm{l}$ $\mathrm{NaH}_{2} \mathrm{PO}_{4}, \mathrm{pH} 7.4$ ), and then washed at $65^{\circ} \mathrm{C}$ in $0.1 \times \mathrm{SSC}$ ( $\mathrm{SSC}=0.15 \mathrm{~mol} / \mathrm{l}$ sodium chloride and $0.015 \mathrm{~mol} / \mathrm{l}$ sodium citrate, $\mathrm{pH} 7.0$ ), $0.1 \%$ SDS (sodium dodecyl sulphate) according to the instructions recommended by the vendor. Blots were exposed to Kodak XAR5 film at $-80^{\circ} \mathrm{C}$ using intensifying screens (Cronex Lightening Plus, E.I. Dupont de Nemours Co., Wilmington, Del., USA). The amount of mRNA present in each sample determined in duplicate was measured by densitometric analysis, comparing the intensity of the sample dot with standard dots.

\section{Quantitation of transporter protein by immunoblotting}

Muscle was homogenized (Brinkman, Westbury, N. Y., USA) on ice at high speed for $45 \mathrm{~s}$ HES buffer $(20 \mathrm{mmol} / 1 \mathrm{Hepes,} 1 \mathrm{mmol} / \mathrm{l}$ EDTA, $250 \mathrm{mmol} / \mathrm{l}$ sucrose, $\mathrm{pH}$ 7.4, 1:20 weight:volume). The protein concentration was determined by the method of Lowry (Sigma Diagnostics, St. Louis, Mo., USA), and samples were analysed by quantitative immunoblotting as previously described [5]. This procedure involves quantitation of the total muscle GLUT4 protein content. Thus, no attempt is made to determine GLUT4 in different muscle fractions. Blots were incubated with phosphate-buffered saline (pH 7.4) containing $50 \mathrm{mg} / \mathrm{ml}$ powdered milk (Carnation Co., Los Angeles, Calif., USA) for $60 \mathrm{~min}$ at $22^{\circ} \mathrm{C}$, and thereafter with a polyclonal antibody specific for the 12 amino acid GLUT4 carboxy terminus [4], and after washing, with ${ }^{125}$ I-labelled protein A (Amersham Corp., Arlington Heights, III., USA). Quantitation was performed by excising labelled bands and counting in a gamma counter. Equal areas away from the band of interest were excised and analysed to establish background. The mean cpm above the background was $325 \pm 36$.
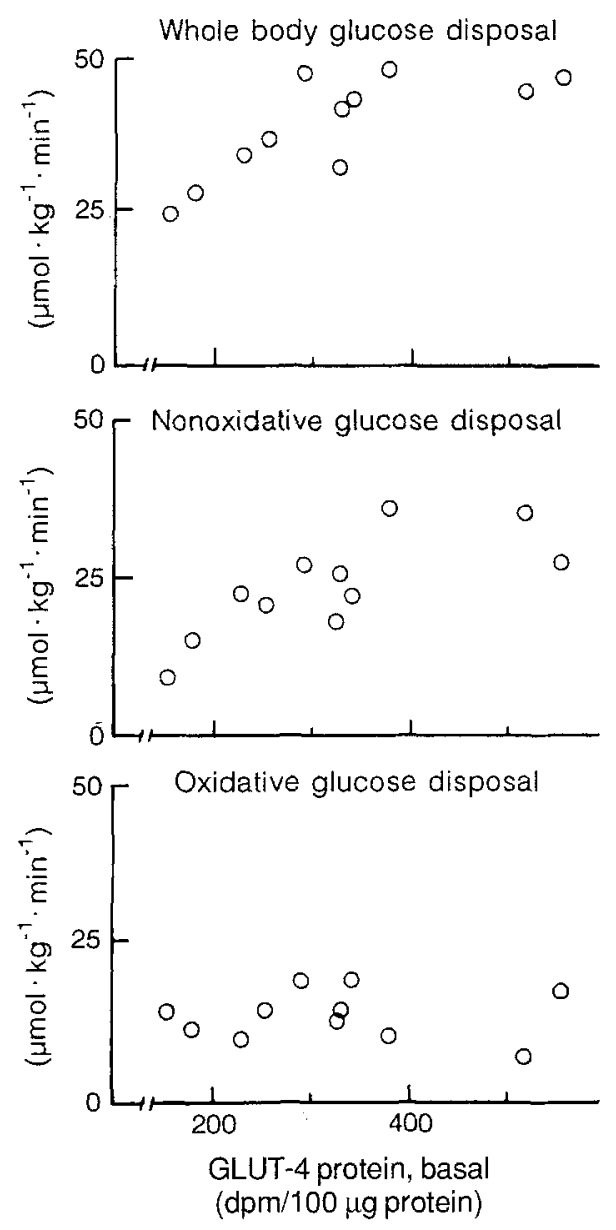

Fig. 1. The relationship between the concentration of the GLUT4 protein in human skeletal muscle biopsies and the rates of total (top panel, $r=0.77, p<0.02$ ), non oxidative (middle panel, $r=0.80$, $p<0.02$ ), and oxidative (bottom panel, $r=0.08$, NS) glucose disposal

\section{Quantitation of plasma glucose and insulin}

Glucose was measured with an automated glucose oxidase method (Beckman Instruments, Fullerton, Calif., USA). Serum free insulin was determined from samples obtained every 30 min during the insulin infusion by RIA (Phadeseph, Pharmacia, Uppsala, Sweden).

\section{Statistical analysis}

Correlation analyses were performed using the non-parametric Spearman's rank correlation coefficient (Statsgraphics, STSC and Statistical Graphics, Rockville, Md., USA).

\section{Results}

Insulin infusion increased the serum-free insulin concentration from $29 \pm 7$ (SEM) to $740 \pm 21$ pmovl. Fasting plasma glucose averaged $5.4 \pm 0.1 \mathrm{mmol} / 1$. During hyperinsulinaemia, normoglycaemia was maintained $(5.3 \pm 0.1 \mathrm{mmol} / \mathrm{l})$. Whole body glucose uptake averaged $38 \pm 2 \mu \mathrm{mol} \cdot \mathrm{kg}^{-1} \cdot \mathrm{min}^{-1}$. Of this, $14 \pm 1 \mu \mathrm{mol} \cdot \mathrm{kg}^{-1}$. $\min ^{-1}$ was oxidized during the $240-\min$ period while 
$24 \pm 2 \mu \mathrm{mol} \cdot \mathrm{kg}^{-1} \cdot \mathrm{min}^{-1}$ was disposed of through nonoxidative pathways.

The GLUT4 mRNA concentration (determined after an overnight fast, i.e. before the insulin infusion) was $26 \pm 5 \mathrm{pg} / \mathrm{\mu g}$ RNA. The GLUT4 mRNA concentration did not correlate with the GLUT4 protein content $(r=0.2)$, the rate of whole body $(r=0.3)$ or non-oxidative glucose disposal $(r=-0.3)$. The muscle content of GLUT4 protein, however, correlated well with whole body glucose disposal and this correlation appears to be specific for non-oxidative as compared to oxidative disposal (Fig.1). The fasting insulin concentration did not correlate with the muscle content of the GLUT4 protein $(r=0.49, \mathrm{NS})$ or GLUT4 mRNA $(r=0.10, \mathrm{NS})$.

\section{Discussion}

Under many conditions, glucose transport appears to be rate-limiting for its metabolism in skeletal muscle $[2,6]$. Because skeletal muscle is the major site of glucose disposal under hyperinsulinaemic, euglycaemic clamp conditions [1], it is widely assumed that the activity of the transport system in muscle is rate-limiting for whole-body, insulin-stimulated glucose disposal. Our data show a correlation between levels of basal GluT4 protein in vastus lateralis muscle and whole-body glucose disposal in normal individuals, providing the first direct support for this assumption. There was no correlation between muscle content of GLUT4 protein and mRNA after an overnight fast. Although we have found a good correlation between these molecules across different muscle types in the rat [5], our present results are in agreement with other published data in man [10].

The major part of whole-body insulin-stimulated glucose disposal was accounted for by non-oxidative glucose disposal, presumably muscle glycogen synthesis [1]. Controversy remains over the site of the rate-limiting step of insulin-stimulated glucose disposal in muscle. The correlation between non-oxidative glucose disposal, which predominantly represents muscle glycogen synthesis [1], and insulin-stimulated glucose disposal would suggest that under the condition of this study, the muscle glucose transporter may be rate-limiting or at least regulated closely in parallel with the rate-limiting process. The smaller oxidative component (mean $14 \mu \mathrm{mol} \cdot \mathrm{kg}^{-1} \cdot \mathrm{min}^{-1}$ ), on the other hand, showed no correlation with muscle glucose transporter content. This finding may be due to the relatively large portion of oxidative metabolism $(-6 \mu \mathrm{mol}$. $\left.\mathrm{kg}^{-1} \cdot \mathrm{min}^{-1}\right)$ which occurs independently of insulin in the central nervous system.

In the present study, the total muscle GLUT4 mRNA and protein contents were also determined in muscle biopsies taken at the end of the 4-h insulin infusion (data not shown). While GLUT4 mRNA increased in all subjects. GLUT4 protein exhibited a significant slight decrease $(-20 \%)$. This finding was recently confirmed in preliminary studies by Handberg et al. [10] who observed an $18 \%$ decrease in GLUT4 protein during a 3 -h insulin infusion.
Whether this decrease represents a transient imbalance between synthesis and utilization of GLUT4, remains to be established. On the other hand, as long as the effect of insulin on the intracellular location of GLUT4 protein in muscle remains unclear, the physiological significance of these data remains uncertain.

In summary, we have demonstrated a correlation between the vastus lateralis muscle GLUT4 protein content and insulin-stimulated whole-body glucose disposal in young normal men. The correlation was specific for nonoxidative glucose disposal. GLUT4 mRNA concentration did not correlate with either the GLUT4 protein content or glucose disposal in these individuals.

Acknowledgements. This research was supported by grants from the Finnish Academy of Science, Finnish Diabetes Association, Nordisk Insulinfond, National Institutes of Health (DK16746, DK38495, DK07120, AG00078), and Juvenile Diabetes Foundation (387269).

\section{References}

1. Yki-Järvinen H, Young AA, Lamkin C, Foley JE (1987) Kinetics of glucose disposal in whole body and across the forearm in man. J Clin Invest 79: 1713-1719

2. Klip A, Paquet MR (1990) Glucose transport and glucose transporters in muscle and their metabolic regulation. Diab Care 13: $228-243$

3. Mueckler M (1990) Family of glucose transporter genes: implications for glucose homeostasis and diabetes. Diabetes 39: 6-11

4. James DE, Strube M, Mueckler M (1989) Molecular cloning and characterization of an insulin regulatable glucose transporter. Nature 338: 83-87

5. Henriksen EJ, Bourey RE, Rodnick KJ, Koranyi LI, Permutt MA, Holloszy JO (1990) Glucose transporter protein content and glucose transport capacity in rat skeletal muscles. Am J Physiol 259: E539-E598

6. Yki-Järvinen H, Sahlin K, Ren JM, Koivisto VA (1990) Localization of rate-limiting defect for glucose disposal in skeletal muscle of insulin-resistant Type 1 diabetic patients. Diabetes 39: $157-167$

7. Green G, Edwards Y, Hauri HP et al. (1987) Isolation of a cDNA probe for human jejunal brush border hydrolase, sucrose-isomaltase, and assignment of the gene locus to chromosome 3. Gene 57: 101-110

8. Fukumoto H, Kyano T, Buse JB et al. (1989) Cloning and characterization of the major insulin responsive glucose transporter expressed in human skeletal muscle and other insulin responsive tissues. J Biol Chem 264: 776-779

9. Pedersen O, Bak JF, Andersen PH et al. (1990) Evidence against altered expression of GLUT1 or GLUT4 in skeletal muscle of patients with obesity or NIDDM. Diabetes 39:865-870

10. Handberg A, Vaag A, Beck-Nielsen H et al. (1991) Effect of hyperinsulinaemic euglycaemic clamp on GLUT4 in human skeletal muscle. Diabetes 40 [Suppl 1]: 88A (Abstract)

Received: 24 May 1991

and in revised form: 19 July 1991

Dr. H. Yki-Järvinen

Second Department of Medicine

Helsinki University

Haartmaninkatu 4

SF-00290 Helsinki

Finland 